\title{
Plant and Soil Biota: Crucial for Mitigating Climate Change in Forests
}

\author{
Marcela C. Pagano ${ }^{1^{*}}$ \\ ${ }^{1}$ Department of Physics, Federal University of Minas Gerais, Belo Horizonte, Minas Gerais, \\ 30123-970, Brazil.
}

Author's contribution

The only author MCP performed the whole research work.

Research Article

Received 24 ${ }^{\text {th }}$ August 2012

Accepted $12^{\text {th }}$ June 2013

Published $31^{\text {st }}$ July 2013

\section{ABSTRACT}

Interest in forestation is rising with increasing recognition that global changes can negatively affect plant diversity and ecosystem function. It is known that forests influence climate through physical, chemical, and biological processes and ecohydrology need substantially more research. Functional interactions among vegetation, soils, and hydrologic processes permit the trees to maintain their symbioses in the soil. However, global change affects forests and soil health, influencing the population, diversity and activities of soil microbes, including symbiotic fungal populations. Although plants are sessile organisms, selected agroforestry tree species (mycorrhizal dependent plants) can be employed in forestation to encompass environmental stresses increased by global changes. This review was done to explore current information on forest for mitigating climate change, with respect to the research results on soil microbiota and its hydrologic impacts. Thus, relevant findings related to the benefits of soil health are emphasized. Accordingly, I discuss interdisciplinary knowledge required to understand the potential of forest to mitigate climate change.

Keywords: Climate change; forestation; soil health; ecohydrology. 


\section{INTRODUCTION}

Interest in forestation is growing with increasing recognition that global changes can negatively affect ecosystem function. Forestation increases the permeability of the soil and emits water vapor into the atmosphere through evaporation and transpiration, further reducing the runoff of rainwater [1]. It is known that forests influence climate through physical, chemical, and biological processes that affect planetary energetics, the hydrologic cycle, and atmospheric composition, and thus they inhibit or magnify anthropogenic climate change [2]. However, there is controversy on the impact of reforestation on water yield by reducing or raising downstream water availability and intensification of the hydrologic cycle [3]. Thus, understanding the general beneficial relationship between forest cover and the intensity of the hydrologic cycle is an urgent need. Moreover, ecohydrology (functional interactions among vegetation, soils, and hydrologic processes and the linkages among upland, riparian, and aquatic parts) needs substantially more research (see [4]). This review is done to explore current information on forest for mitigating climate change, with respect to the research results on soil microbiota and its hydrological impacts. First, I will consider land use changes and their effect on forestation for ecosystem services. Subsequently, I will focus on the climate change effects on forestation and their belowground interactions. Finally, the importance of mycorrhizal interactions for reforestation will be discussed with a focus on riparian forests.

\section{LAND USE CHANGE}

Deforestation, involving land conversion from forest to agriculture and urbanization, affects global precipitations, and land management needs to consider the connection of forests to the supply of precipitation [3]. Tree cover affects the soil physical and chemical properties, modifying the number, diversity and activity of the soil microbiota, including both free and symbiotic fungal populations (Fig. 1). Trees also increase the carbon (C) sequestration providing wood supply for local communities; however, $C$ sequestration strategies highlight tree plantations without considering their full environmental contributions, such as losses in stream flow [1]. Therefore, it has been shown that placing a value on ecosystem services (forest services) helps to preserve water supply [5].

It has also been shown that as forests are under remarkable pressure from global change, interdisciplinary knowledge is required to identify and understand their potential to mitigate the effects of climate changes [2] (Table 1). Moreover, old-growth forests, which provide unique values, need more research, in order to conserve them and understand their stability [6].

Global changes also affect river ecosystems e.g. water flow disruptions, temperature rises, loss of hydrological connectivity, altered water residence times, changes in nutrient loads, increased arrival of new chemicals, simplification of the physical structure, presence of invasive species, and biodiversity losses [7]. Thus, rivers are threatened by changes in land use, climate, hydrologic cycles, and biodiversity, which affect their structure and functioning. In this regard, the study of responses of river ecosystems to global change is vital for human welfare. Rivers provide food, irrigation [7] and their health requires an integrated basin management, with protection of aquatic and riparian biodiversity [8]. For example, approximately 13,400 fish species live in freshwater ecosystems, many as small rare populations [8]. Vose et al. [4] stressed that challenges in forest ecohydrological research should concentrate on understanding watershed responses to climate change and to losses 
of native species or additions of exotic species, as well as on managing forested watersheds to adapt to climate change. For example, hazardous events such as floods, which are still rising compared to earthquakes, must be investigated with regard to global warming [9].

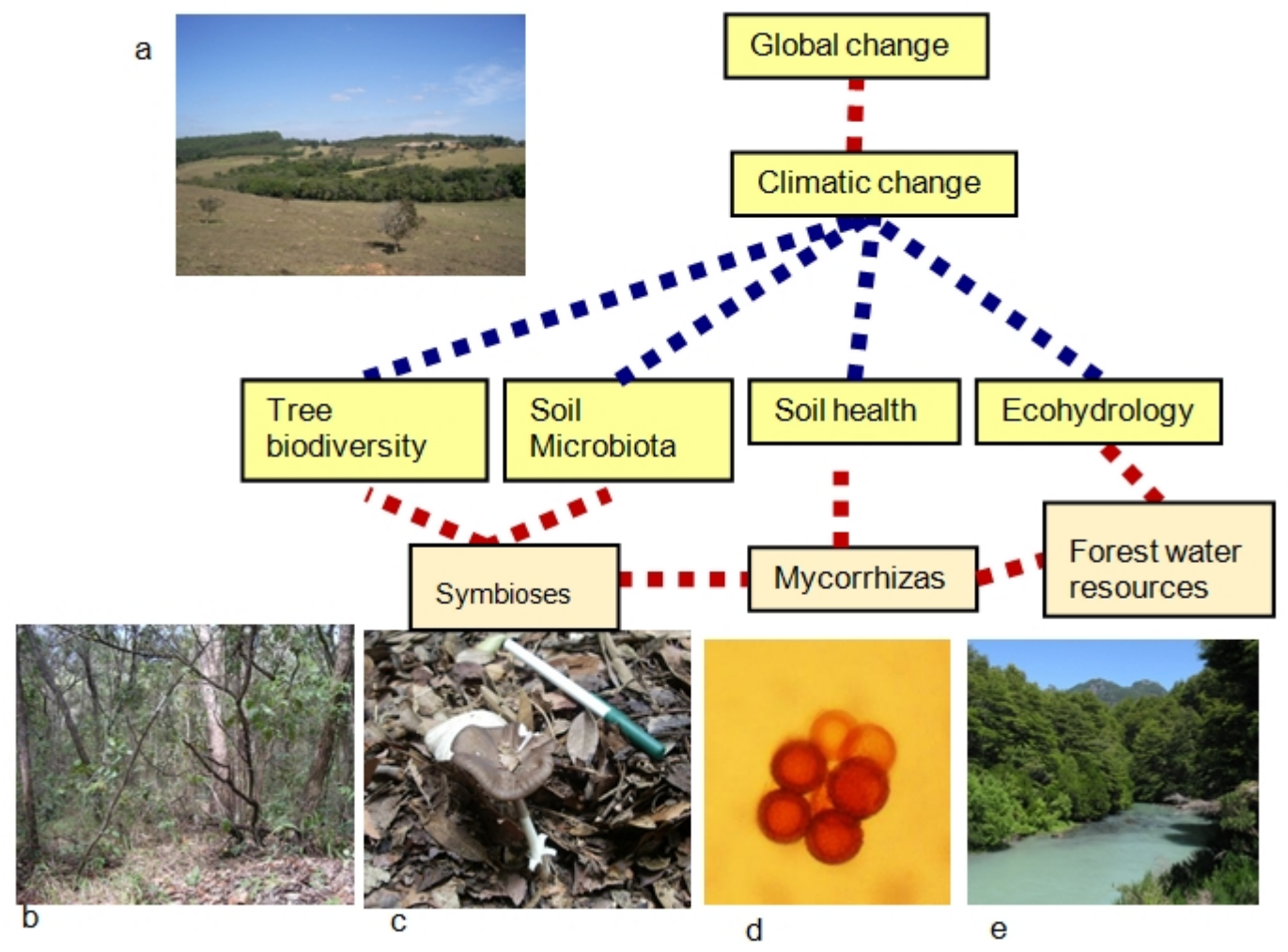

Fig. 1. Global change (a) including climatic change result in altered ecosystems tree biodiversity (b), soil microbiota (c) soil health and soil symbionts, such as arbuscular mycorrhizas (d), contributing to conditions that allow for forest water resources (e) changes (Photo credit - M. Pagano)

Table 1. Summary of actual evidence on forest ecosystem services in mitigating climate change and its hydrological impacts

\begin{tabular}{lll}
\hline Location & Forestation type & Source \\
\hline Major river basins & Forest cover & Ellison et al. [3] \\
Worldwide & Watershed structure and function & Vose et al. [4] \\
Tropics & Reforestation & Pagano and Cabello [1] \\
USA & Managed and unmanaged forests & Elliott and Vose [10] \\
Worldwide & Forests & Wei et al. [11] \\
Temperate zones & Forests (afforestation) & South et al. [12] \\
Worldwide & Forests & Bonan [2] \\
\hline
\end{tabular}

The riparian vegetation is associated to the bank of stream channels, having characteristics of ecotones with delicate balances of biotic and abiotic patterns [13]. It is known that riparian zones are complex and important ecosystems due to their function as buffers that play an important role in the movement of water and pollutants to surface water bodies and ground 
water, decreasing land erosion by water [14]. Floodplain forests have been greatly reduced by agriculture and river control has altered the natural flooding and disturbance regime, influencing nutrient cycling, plant growth and soil structure, thus decreasing water retention, resistance to erosion, root development, and microbial activity [15]. Several countries have suffered from increasingly frequent and costly natural disasters of floods, which are demoralizing [16]. Forest protection or regeneration of forest upstream of a region has been proposed for reducing floods, which maintains stream flows during dry periods [17]. The challenge of predicting responses of rivers to global change has been pointed out due to the complexity of interactions among anthropogenic drivers across the miscellany of natural hydrogeomorphic and climates [7].

Functional and structural restoration of riparian sites in Brazil (Fig. 2), for example, using tropical tree legumes can illustrate river-soil interaction [18]. A study of Centrolobium tomentosum, which forms symbiosis with fast- and slow-growing rhizobial strains, revealed that flood disturbances do not affect root renodulation by fast-growing Rhizobium strains; however, slow strains (Bradyrhizobium sp., also found in preserved sites) can also have an important role as they increase after flooding. The information gathered could help to develop an understanding of the desired plant inoculation (nursery culture by selected strains).

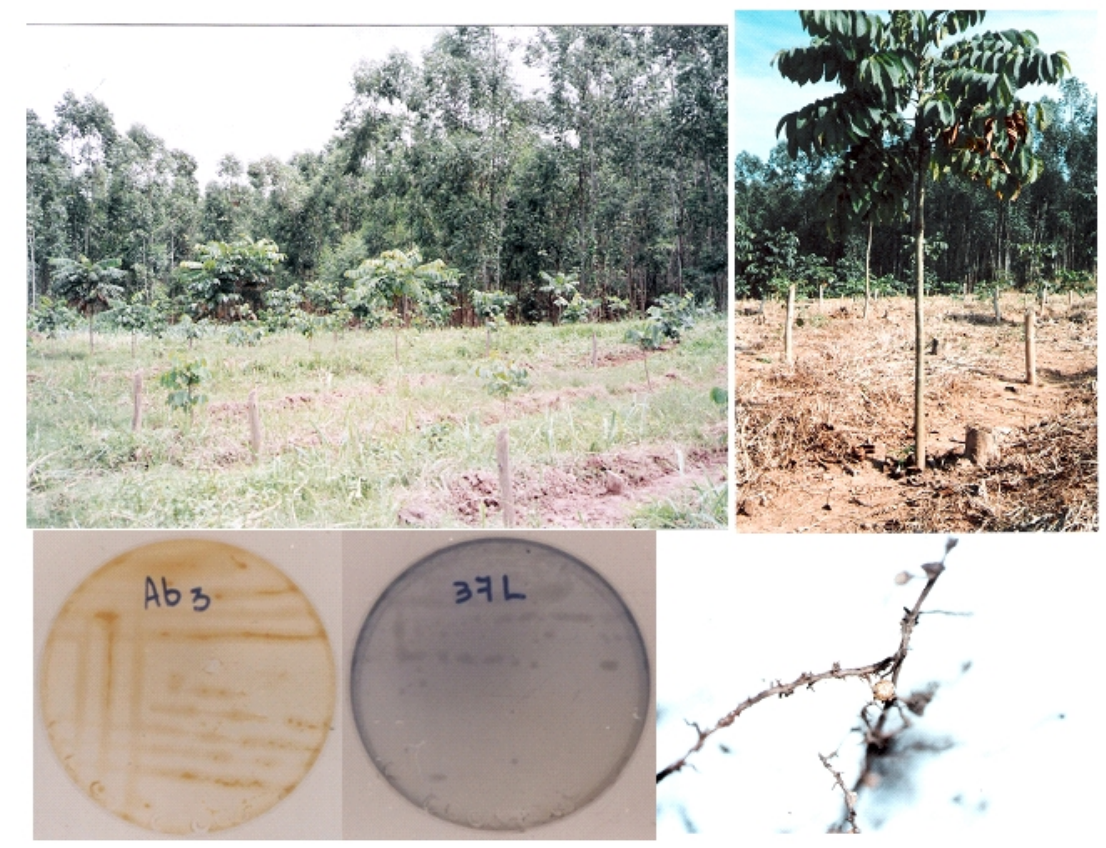

Fig. 2. Monoculture of Centrolobium tomentosum under different inoculation in Brazilian riparian forest. Clockwise, from upper left: cultivated site; nodulated root; and rhizobia isolated from their nodules (slow strain and fast strain) (Photo credit - $M$. Pagano)

Approaches to the recovery of ecosystem services by drawing on soil services, soil biodiversity and on current thinking on ecosystem restoration to attain a better understanding of ecosystems need connectivity areas such as corridors assisting organisms to respond 
and survive the biome shifts caused by global change. Therefore, an understanding and cooperation between researchers, policy makers and the community is required.

\section{CLIMATIC CHANGE}

There is growing recognition that climate change and a growing imbalance among freshwater supply, consumption, and population are altering the water cycle dramatically [19]. Particularly vulnerable to climatic change are river networks, whose structure and functions respond to managements of their hydrology [8]. Some fishes, for example, are more sensitive to climate change than to land cover change [20].

Moreover, increasing soybean production has devastated the rich native biota of the savannas, the Amazonian forest and native vegetation in Argentina. This high deforestation rate resulted in numerous areas which suffer water shortages due to climate change caused by the felling of the forests [21].

Some nations nowadays support international research programs of sustainable coastal management (e.g. the international research program 'Sustainable Land Management' funded by the Federal Ministry for Education and Research of Germany) to adapt to climate change or research focused on soil restoration, such as using biochar [22]. In this sense, the use of biochar (low-density charred material produced by burning biomass under conditions of low temperatures and minimal oxygen) has received increased interest as a sustainable tool to improve poor or degraded soils. Although biochar can enhance plant growth by improving chemical, physical and biological soil properties, contributing to an increased crop/plant productivity $[23,24]$, further experimental research is needed.

However, urban constructions disregarding the natural cycles mitigated by mangroves and promoting riparian vegetation suppression are increasing in Brazil. Fortunately, in Brazil, some researchers are focusing on restoration efforts such as native tree planting and the promotion of natural forest regeneration and reconnection in the Atlantic Forest fragments [25]. With regard to semi-arid environments, forests take up $\mathrm{CO}_{2}$ and enhance absorption of solar radiation, with contrasting effects on global temperature. Moreover, in Israel, the desertification in those environments can contribute to $\sim 20 \%$ of the global anthropogenic $\mathrm{CO}_{2}$ [26].

\section{PLANT AND SOIL BIOTA}

Factors controlling soil microbial diversity remain controversial; however, major determinants of the structure of microbial communities in soil, are soil or plant type [27]. Moreover, Fierer and Jackson [28] observed soil $\mathrm{pH}$ as the best predictor of bacterial diversity, suggesting that microbial biogeography is controlled primarily by edaphic factors.

Plants are sessile organisms open to natural climatic or edaphic stresses (high irradiation, heat, frost, drought, flooding, nutrient inequalities) and to environmental changes from human doings e.g. soil and air pollution, land degradation, etc. [29]. Nevertheless, the choice of selected agroforestry tree species especially, highly mycorrhizal dependent plants, would have great implications for the tolerance of plants. The manipulation of arbuscular mycorrhizal fungi (AMF) species would also bring more benefit. 
The fact that vegetation type modifies the rhizosphere-associated microbial communities is nowadays borne in mind [30,31] due to their effect on native microbial populations in soil selecting specific microbial populations mainly by root exudates [30]. And this is crucial as it is known that the long-term treatment of vegetation is the simplest solution for land restoration, allowing natural or artificial succession [32]. Therefore, there are several contrasting reports in the literature designating soil or plant type as the dominant factor for bacterial occurrence [33], for bacteria, pseudomonads and total fungi [34] as well as for arbuscular mycorrhizal fungi $[31,35,36,37]$. Previous reviews focused on bacteria and total fungi [27]; however, Barea et al. [38,39] as well as Millard and Singh [40] considered AMF as key microorganisms of soil microbiota. Nonetheless, little attention has been paid to AMF, extremely successful microfungi that form mutualistic symbioses with $80 \%$ of all plant species, as important components of the soil microbial community.

Recently, AMF contribution from aquatic to terrestrial habitats by connecting plants, soil, and ground water, has been recognized [41] and their influence on nutrient transfer among riparian ecosystems suggested. In Brazil, for instance, Pagano and Cabello [42] reported the occurrence and benefits of AMF in reforested riparian areas. AMF participate in ecosystem services such as increasing soil structure, protecting soil carbon (C) against mineralization, and protecting tree roots against disease or drought [43]. Moreover, it is known that mycorrhizas and black C (biochar) are theoretically essential in various soil ecosystem services, contributing to sustainable plant production, ecosystem restoration, and soil C sequestration and hence mitigation of global climate change [44].

For example, in temperate climatic zones of Central Europe, Oehl et al. [35] highlight that land use intensity and soil type strongly affect AMF community composition, presence and prevalence in soils. Also in the semiarid region of Brazil, Pagano et al. [31] observed changes in AMF communities in different vegetation covers. Increasing experiments on soil microorganisms and especially AMF have showed that "future climate" such as warming and atmospheric $\mathrm{CO}_{2}$ stimulates AMF root colonization; however, the beneficial effect of AMF on grassland productivity is only expressed when root competition for nutrients is present and AMF have access to a root-free soil compartment [45].

\section{CONCLUSION}

The analysis of recent papers such as those mentioned above suggests that global change affects forests and soil health, influencing the population, diversity and activities of soil microbes, including plant symbiotic fungal populations. There is still controversy about the impact of reforestation on water yield (reducing or raising downstream water availability); thus, ecohydrology requires substantially more research. Other factors such as declining riparian vegetation, river pollution and declining soil fertility due to increasing soybean production, which has devastated the rich native forest, have also been reported as responsible for the observed changes. International research programs of sustainable coastal management to adapt to climate change have been undertaking a number of accomplishments, but these efforts deal with urban constructions and suppression of riparian vegetation, disregarding the natural cycles mitigated by forest.

The climatic changes and the deforestation activities suggest the need for future changes in the selection of agroforestry tree species to encompass environmental stresses and the need to redesign research and extension support programs to include new technologies to be employed in forestation. 


\section{COMPETING INTERESTS}

Author has declared that no competing interests exist.

\section{REFERENCES}

1. Pagano MC, Cabello MN. Mycorrhizal Interactions for Reforestation: Constraints to Dryland Agroforest in Brazil. ISRN Ecology. 2011;1:13. doi:10.5402/2011/890850

2. Bonan GB. Forests and climate change: Forcings, feedbacks, and the climate benefits of forests. Science. 2008;320:1444-1449.

3. Ellison D, Futter MN, Bishop K. On the forest cover-water yield debate: From demandto supply-side thinking. Glob Change Biol. 2012;18:806-820.

4. Vose JM, Sun G, Ford CR, Bredemeier M, Otsuki K, Wei X, et al. Forest ecohydrological research in the 21st century: What are the critical needs? Ecohydrology. 2011;4:146-158.

5. Russo G. Biodiversity: biodiversity's bright spot. Nature. 2009;462(7271):266-269.

6. Hendrickson O. Old-growth forests: Data gaps and challenges. Forest Chronicle. 2003;79:645-651.

7. Stevenson RJ, Sabater S. Understanding effects of global change on river ecosystems: science to support policy in a changing world. Hydrobiologia. 2010;657:3-18.

8. Décamps H. River networks as biodiversity hotlines. CR Biol. 2011;334:420-434.

9. Mitchell T, Ibrahim M, Harris K, Hedger M, Polack E, Ahmed A, et al. Climate Smart Disaster Risk Management, Strengthening Climate Resilience,Brighton: IDS; 2010.

10. Elliott KJ, Vose JM. The contribution of the Coweeta Hydrologic Laboratory to developing an understanding of long-term (1934-2008) changes in managed and unmanaged forests. Forest Ecol Manag. 2011;261:900-910.

11. Wei X, Sun G, Vose JM, Otsuki K, Zhang Z, Smetterm K. Forest ecohydrological processes in a changing environment. Ecohydrology. 2011;4:143-145.

12. South DB, Lee $X$, Messina MG. Will afforestation in temperate zones warm the Earth? J Hortic Forestry. 2011;3:195-199.

13. Naiman RJ, Décamps H. The Ecology of Interfaces: Riparian Zones. Annu Rev Ecol Syst. 1997;28:621-58.

14. Schultz RC, Isenhart TM, Simpkins WW, Colletti JP. Riparian forest buffers in agroecosystems - lessons learned from the Bear Creek Watershed, central lowa, USA. Agroforest Syst. 2004;61:35-50.

15. Sanginga N, Mulongoy I, Swift MJ. Contribution of soil organisms to the sustainability and productivity cropping systems in the tropics. Agr Ecosys Environ. 1992;41:135152.

16. Laurance WF. Environmental science: forests and floods. Nature. 2007;449(7161): 409-410.

17. Bradshaw CJA, Sodhi NS, Peh KSH, Brook BW. Global evidence that deforestation amplifies flood risk and severity in the developing world. Glob Change Biolog. 2007;13:2379-2395.

18. Pagano MC. Rhizobia associated with neotropical tree Centrolobium tomentosum used in riparian restoration. Plant Soil Environ. 2008;54(11):498-508.

19. Jackson RB, Carpenter SR, Dahm CN, McKnight DM, Naiman RJ, Postel SL, et al. Water in a changing world, Ecol Appl. 2001;11(4):1027-1045. 
20. Wiley MJ, Hyndman DW, Pijanowski BC, Kendall AD, Riseng C, Rutherford ES, et al. A multi-modeling approach to evaluating climate and land use change impacts in a Great Lakes River Basin. Hydrobiologia. 2010;657:243-262.

21. Solbrig OT. The dilemma of biodiversity conservation. In: Agricultural expansion in the Argentine Pampas. Harvard Review of Latin America, Flora and Fauna III. 2005;1:3435.

22. Paulsch C, Werntze A. Research programme, sustainable land management and its contribution to ecosystem restoration. In: Contribution of ecosystem restoration to the objectives of the CBD and a healthy planet for all people. Montreal: Secretariat of the Convention on Biological Diversity; 2011.

23. Glaser B, Lehmann J, Zech W. Ameliorating physical and chemical properties of highly weathered soils in the tropics with bio-char - a review. Biol Fert Soils. 2002;35:219230.

24. Yamato M, Okimori Y, Wibowo IF, Anshiori S, Ogawa M. Effects of the application of charred bark of Acacia mangium on the yield of maize, cowpea and peanut, and soil chemical properties in South Sumatra, Indonesia. Soil Sci Plant Nutr. 2006;52:489495.

25. Brancalion PHS, Castro P, Rodrigues RR, Aronson J. The Atlantic Forest Restoration Pact-A major effort by Brazilian society to restore and transform its most threatened biome. In: Contribution of Ecosystem Restoration to the Objectives of the CBD and a Healthy Planet for All People. Montreal: Secretariat of the Convention on Biological Diversity; 2011.

26. Rotenberg E,_Yakir D. Contribution of Semi-Arid Forests to the Climate System. Science. 2010;327(5964):451-454.

27. Garbeva P, van Veen JA, van Elsas JD. Microbial diversity in soil: Selection of Microbial Populations by Plant and Soil Type and Implications for Disease Suppressiveness. Annu Rev Phytopathol. 2004;42:243-270.

28. Fierer N, Jackson RB. The diversity and biogeography of soil bacterial communities. $P$ Nat Acad Sci USA. 2006;103:626-631.

29. Schützendübel A, Polle A. Plant responses to abiotic stresses: heavy metal-induced oxidative stress and protection by mycorrhization. J Exp Bot. 2002;53:1351-1365.

30. Ber G, Smalla K. Plant species and soil type cooperatively shape the structure and function of microbial communities in the rhizosphere. FEMS Microbiol Ecol. 2009;68:1-13.

31. Pagano MC, Utida MK, Gomes EA, Marriel IE, Cabello MN, Scotti MR. Plant-type dependent changes in arbuscular mycorrhizal communities as soil quality indicator in semi-arid Brazil. Ecol Indic. 2011;11(2):643-650.

32. Bradshaw $A D$. The reclamation of derelict land and the ecology of ecosystems. In: Jordan III WR, Gilpin ME, Aber JD, editors. Restoration ecology. A synthetic approach to ecological research. Cambridge University press; 1987.

33. Girvan MS, Bullimore J, Pretty JN, Osborn AM, Ball AS. Soil type is the primary determinant of the composition of the total and active bacterial communities in arable soils. Appl Environ Microbiol. 2003;69:1800-1809.

34. Grayston SJ, Wang S, Campbell CD, Edwards AC. Selective influence of plant species on microbial diversity in the rhizosphere. Soil Biol Bioch.1998;30:369-378.

35. Oehl F, Laczko E, Bogenrieder A, Stahr K, Bösch R, van der Heijden M, et al. Soil type and land use intensity determine the composition of arbuscular mycorrhizal fungal communities. Soil Biol Biochem. 2010;42:724-738.

36. Miransari M. Interactions between arbuscular mycorrhizal fungi and soil bacteria. Appl Microbiol Biotechnol. 2011;89:917-930. 
37. Pagano MC, editor. Mycorrhiza: Occurrence and role in natural and restored environments. Hauppauge (NY): Nova Science Publishers; 2012.

38. Barea JM, Azcón R, Azcón-Aguilar C. Mycorrhizosphere interactions to improve plant fitness and soil quality. A van Leeuw. 2002;81:343-351.

39. Johansson JF, Paul LR, Finlay RD. Microbial interactions in the mycorrhizosphere and their significance for sustainable agriculture. FEMS Microbiol Ecol. 2004;48:1-13.

40. Millard $P$, Singh BK. Does grassland vegetation drive soil microbial diversity? Nutr Cycl Agroecosys. 2009;88:147-158.

41. Harner MJ, Opitz N, Geluso K, Tockner K, Rillig MC. Arbuscular mycorrhizal fungi on developing islands within a dynamic river floodplain: an investigation across successional gradients and soil depth. Aquat Sci. 2011;73:35-42.

42. Pagano MC, Cabello MN. Mycorrhizas in natural and restored riparian zones. In: Pagano MC, editor. Mycorrhiza: Occurrence in natural and restored environments, Hauppauge (NY): Nova Science Publishers; 2012.

43. Simard SW, Austin ME. Climate Change and Variability. Rijeka, SCIYO; 2010.

44. Warnock DD, Lehmann J, Kuyper TW, Rillig MC. Mycorrhizal responses to biochar in soil - concepts and mechanisms. Plant Soil. 2007;300:9-20.

45. Büscher M, Zavalloni C, Boulois HD, Vicca S, Berge J, Declerck S, et al. Effects of arbuscular mycorrhizal fungi on grassland productivity are altered by future climate and below-ground resource availability. Environ Exp Bot. 2012;81:62-71.

(c) 2013 Pagano; This is an Open Access article distributed under the terms of the Creative Commons Attribution License (http://creativecommons.org/licenses/by/3.0), which permits unrestricted use, distribution, and reproduction in any medium, provided the origin al work is properly cited.

Peer-review history:

The peer review history for this paper can be accessed here: http://www.sciencedomain.org/review-history.php?iid=251\&id=10\&aid=1786 